技術論文

\title{
超音波を用いたリアルタイム位置測位システムの開発
}

\section{Development of Real-time Positioning System by ultrasonic waves}

\author{
松岡俊佑 ${ }^{* 1}$ (正員)，藤枝直輝 ${ }^{* 1} ，$ 市川周一 ${ }^{* 1} ， 川 口$ 秀樹 ${ }^{* 2}$
}

Shunsuke Matsuoka (Mem.), Naoki Fujieda, Shuichi Ichikawa, Hideki Kawaguchi

\begin{abstract}
This paper presents a real-time positioning system for indoor use, which utilizes ultrasonic waves. Many existing systems were prevented from real-time applications by long detection time and calculation time. The proposed system utilizes multiple frequencies of ultrasonic waves, which lead to the reduction of positioning interval and system complexity. We developed our prototype system with Arduino Uno, and achieved $30 \mathrm{~ms}$ of the positioning interval.
\end{abstract}

Keywords: Ultrasonic wave, Positioning system, GPS

\section{1 緒言}

位置測位システムは，電波などの伝搬遅延時間を利 用して送受信機間の距離を測定し，それらをもとに測 定対象の位置を求めるシステムである. 最も広く利用 されている位置測位システムは GPS [1] であるが, GPS は衛星からの電波を用いて測位するため, 室内な ど電波が受信しにくい環境では利用が難しい. 室内用 としては，無線 LAN のアクセスポイントからの電波 や，LED 照明を利用した可視光通信による測位システ ムが提案されている[2-4] . しかし電磁波は光速で伝搬 するため, 非常に高精度な時間計測が必要であり, 測 位誤差は数 $\mathrm{m}$ 程度と大きい. そのため, 室内など限ら れた狭い空間での高精度な測位には不向きである.

超音波を利用した位置測位システム [5] は，近距離 の測位に限定されるが，音速が $340 \mathrm{~m} / \mathrm{s}$ 程度であるた め高精度な測位が可能である。オンオフ変調方式 [6] では，複数送信機からの信号を受信機側で順番に時分 割で受信する. スペクトル拡散方式 [7-9] は GPS でも 用いられている方式で，送信機ごとに相異なる符号を 掛けあわせて送信することで, 複数の送信機からの信 号を同時に受信できる。逆 GPS 方式 [10] では測位さ れる側が送信機を持ち, 設置された受信機へ超音波を 送信する.

連絡先： 松岡 俊佑, $\bar{T} 441-8580$ 豊橋市天伯町雲雀ヶ丘 $1-1$, 豊橋技術科学大学電気・電子情報工学系,

e-mail: matsuoka@ee.tut.ac.jp

${ }^{* 1}$ 豊橋技術科学大学 ${ }^{* 2}$ 室蘭工業大学
オンオフ変調方式や逆 GPS 方式では, 一般に送信機 の数に比例して測位間隔が増大する。スペクトル拡散 方式では変調処理の計算負荷が大きいため，専用ハー ドウェアによる高速化[9]を適用しても，測位間隔は $100 \mathrm{~ms}$ 程度にとどまる [11]. そのため，これらの関 連研究は室内にいる多数の人やロボットの動きをリア ルタイムで測位することには向いていない.

本研究では，屋内施設における低コストかつ高速な リアルタイム測位を目的として，周波数の異なる超音 波を用いた測位方式を提案する。時分割処理や複雑な 計算なしに送信信号を選別でき，受信機の数が増えて も一定間隔で測位できるため, 従来の方式よりも測位 の高速化が可能となる. ローエンドな 8 ビットマイコ ン ATmega328P 搭載の ArduinoUno を用いてプロトタ イプシステムを構築し, 測位間隔 $30 \mathrm{~ms}$ 以内, 測位誤 差 $10 \mathrm{~cm}$ 以内を実現したので報告する.

\section{2 超音波位置測位システム}

\section{1 超音波による測位の原理}

超音波を用いた位置測位のモデルを Fig. 1 に示す. 室内，ないし測位対象の空間の天井角隅に超音波送信 機を設置する. 座標 $(x, y, z)$ を求めるため, 送信機は最 低 3 つ必要である。送信機 $n$ の室内における位置を それぞれ $\left(q_{n x}, q_{n y}, q_{n z}\right)$, 測定された送信機 $n$ と受信 機との間の距離を $r_{n}$ と表せば，受信機の位置 $(x, y, z)$ は以下の連立方程式で求められる. 


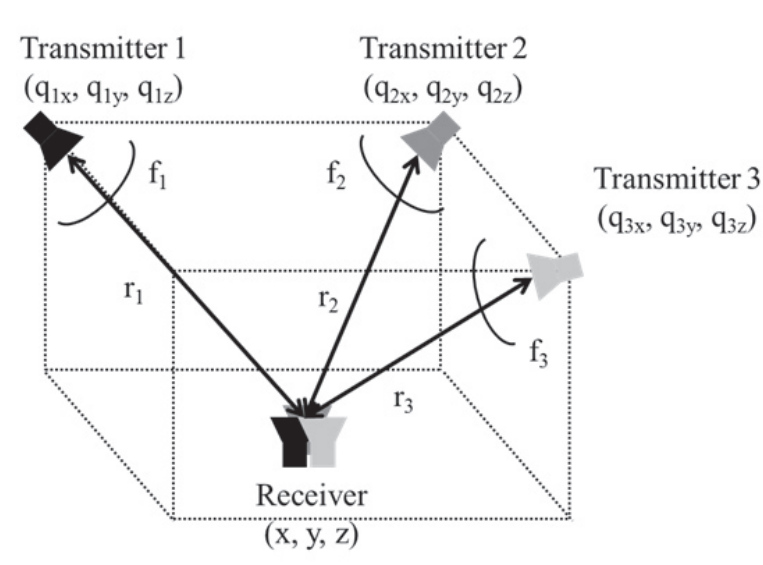

Fig. 1. Indoor positioning model with 3 transmitters.

$$
\begin{aligned}
& r_{1}^{2}=\left(q_{1 x}-x\right)^{2}+\left(q_{1 y}-y\right)^{2}+\left(q_{1 z}-z\right)^{2} \\
& r_{2}^{2}=\left(q_{2 x}-x\right)^{2}+\left(q_{2 y}-y\right)^{2}+\left(q_{2 z}-z\right)^{2} \\
& r_{3}^{2}=\left(q_{3 x}-x\right)^{2}+\left(q_{3 y}-y\right)^{2}+\left(q_{3 z}-z\right)^{2}
\end{aligned}
$$

送信機 $n$ から受信機までの超音波の伝搬遅延時間を $\Delta \mathrm{t}_{n}$, 音速を $v$ としたとき, 距離 $r_{n}$ は $r_{n}=v \Delta \mathrm{t}_{n}$ で 求められる.

連立方程式(1)〜(3)を Newton 法などで数值的に解け ば，求める座標 $(x, y, z)$ が計算できる. しかし，この 方法では計算量が多く, 安価なローエンドマイコンを 用いた場合は計算時間の長さが問題となる.

Fig. 1 のモデルにおいて, 多くの先行研究では送信 周波数（周波数帯域）が全ての送信機で共通であり， 時分割または符号の掛け合わせによって個々の送信機 を認識している，時分割を用いる場合は個々の送信機 を利用可能な時間が送信機の数に反比例して減少し, 符号の掛けあわせを用いる場合は変調処理の計算負荷 が大きい。これらはいずれも測位間隔の増大, 寸なわ ちリアルタイム性の低下を招く.

\section{2 異なる周波数の超音波による測位システム}

本研究では, 周波数の異なる超音波を用いる.すなな わち各送信機はそれぞれ異なる周波数 $f_{1}, f_{2}, f_{3}$ の 超音波を送信寸る。これにより，システムを単純かつ 廉価にしつつ, リアルタイム性の向上を図る.

提案するシステムの概要を Fig. 2 に示す. 送信機は Fig. 1 に示したとおり天井角隅に最低 3 つ設置される が，図中ではそのうちの1つのみを示している。伝搬 時間測定のため送信機と受信機で時刻を同期する必要 があるが，ロボット等では操縦やデータ通信のための 無線通信機能を備えているため, 無線で時刻を同期す

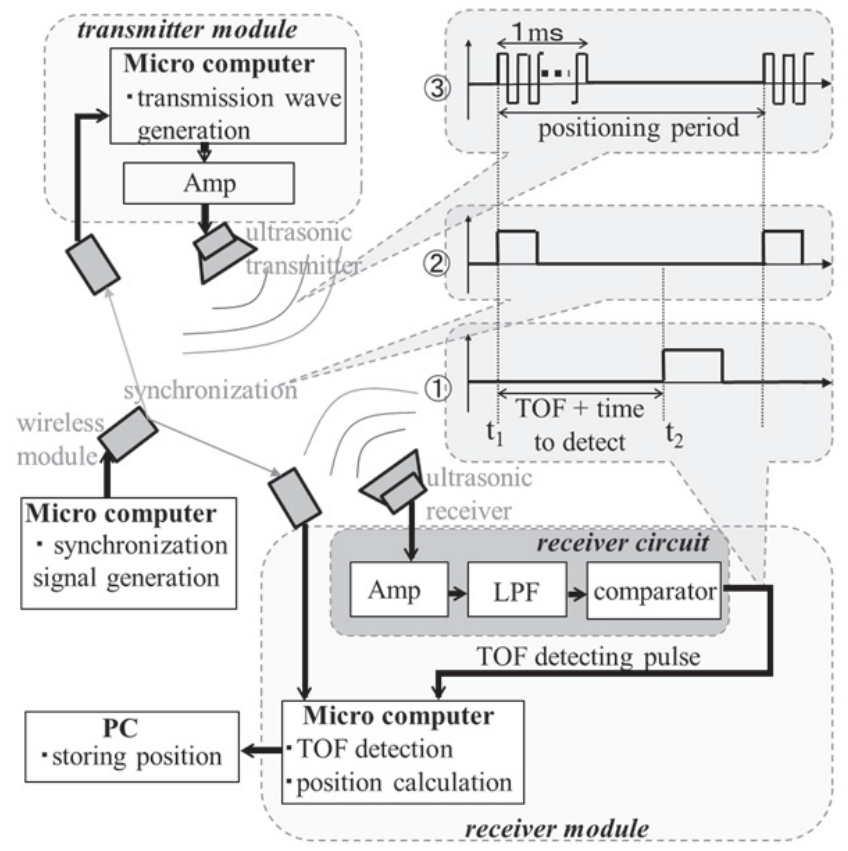

Fig. 2. Overview of proposed positioning system.

るものとする. 同期信号（Fig.2 中の(2)）はマイコンに より生成し，無線モジュールにより送信機・受信機へ と送る.

送信機は開始時刻 $\mathrm{t}_{1}$ から $1 \mathrm{~ms}$ の間だけ方形波を出力 する (Fig.2 中の(3)). 受信された波形は, アンプで増 幅され, ローパスフィルタで整形後に, 比較回路を用 いてシャープな方形波（TOF detecting pulse）へと変換 される．簡易なアナログ回路で送信機（周波数）毎に TOF detection pulse (Fig.2 中の (1) を生成することによ り，コストと遅延時間を削減することができる.

受信機のマイコンは送信開始時刻 $\mathrm{t}_{1}$ から TOF detecting pulse までの遅延時間 $\mathrm{t}_{2}$ (TOF: Time of Flight) を測定し, 音速を掛けて送受信機間の距離を算出する. 全ての送信機からの距離が算出されたら, 受信機の位 置を計算し (2.3 節参照), 結果をホスト $\mathrm{PC}$ 一送信す る.

\section{3 位置の計算の高速化}

室内での測位では，一般に送信機を設置する位置を 任意に選ぶことができる，送信機の位置・個数に制約 を加えると，簡単な計算で位置を測ることができる.

まず，3 つの送信機を同じ高さに設置する場合を考 える. 即ち $q_{1 z}=q_{2 z}=q_{3 z}$ とした場合, 式(2) - (1), および式(3) - (2)によって $z$ を含む項が除去でき, 以 下の 2 元連立 1 次方程式を得る. 


$$
\begin{aligned}
& 2\left(q_{2 x}-q_{1 x}\right) x+2\left(q_{2 y}-q_{1 y}\right) y \\
& \quad=r_{2}^{2}-r_{1}^{2}-q_{1 x}^{2}+q_{2 x}^{2}-q_{1 y}^{2}+q_{2 y}^{2} \\
& 2\left(q_{3 x}-q_{2 x}\right) x+2\left(q_{3 y}-q_{2 y}\right) y \\
& \quad=r_{3}^{2}-r_{2}^{2}-q_{2 x}^{2}+q_{3 x}^{2}-q_{2 y}^{2}+q_{3 y}^{2}
\end{aligned}
$$

これを解けば, 受信機の $(x, y)$ 座標が高速に計算でき る. $z$ 座標は, 求めた $(x, y)$ 座標を式(1), (2), あるい は(3)に代入して得られる2次方程式により求められる. 受信機を同じ高さに設置できない場合，送信機を 4 つに増やすことにより, 高速な計算が可能となる. 送 信機 1 と 2,2 と 3,3 と 4 について測位式の差を取る と, $x^{2}, y^{2}, z^{2}$ の項が除去され, 以下の 3 元連立 1 次 方程式を得る.

$$
\begin{aligned}
& r_{1}^{2}-r_{2}^{2}+K_{1}=A_{11} x+A_{12} y+A_{13} z \\
& r_{2}^{2}-r_{3}^{2}+K_{2}=A_{21} x+A_{22} y+A_{23} Z \\
& r_{3}^{2}-r_{4}^{2}+K_{3}=A_{31} x+A_{32} y+A_{33} Z
\end{aligned}
$$

ここで $K_{1} \sim K_{3}, A_{11} \sim A_{33}$ は送信機の座標で決まる定 数である. これを解くことにより, 反復計算なしに $(x, y, z)$ 座標を求めることができる.

本研究では送信機・受信機間の同期が（無線など他 の方法で）保証されているとした．しかし仮に同期が 保証されない場合でも, 送信機・受信機を 1 組多く用 いることにより，上と同様の方法で座標と時刻の変異 を高速に求めることができる.

超音波は指向性が高いため, 広い範囲を測位するこ とが難しい、広範囲で測位する, 或いは障害物の影響 を避けるには，送信機を多く設置して，受信できた任 意の 4 送信機から位置を計算すればよい.

\section{4 測位周期}

超音波の検出と座標計算の処理がオーバーラップで きないと仮定すると，測位時間は，超音波の伝搬遅延 時間, 超音波の検出にかかる時間 (検出時間), 位置計 算にかかる時間 (計算時間) の総和となる. そのため, 測位周期は超音波の最大伝搬遅延時間（max. TOF） と 検出時間, 計算時間の総和よりも大きく設定しなけれ ばならない. 最大伝搬遅延時間は, 主に測位対象の空 間の大きさにより変化する. 測位対象の空間を直方体 とすれば，最大伝搬遅延時間はその対角線の長さを音 速で除したものとなる.

例えば，測位範囲として $6 \mathrm{~m} \times 6 \mathrm{~m} \times 3 \mathrm{~m}$ の室内を想 定するなら，対角線長は $9 \mathrm{~m}$ であるから，音速を 340

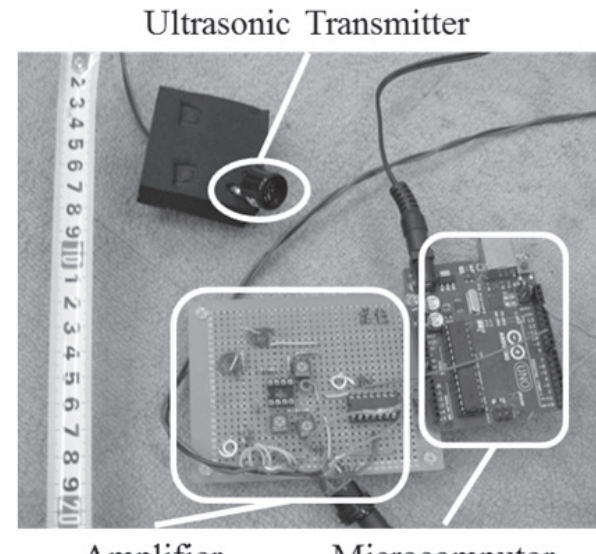

Amplifier Microcomputer

Fig. 3. Photograph of transmitter module.

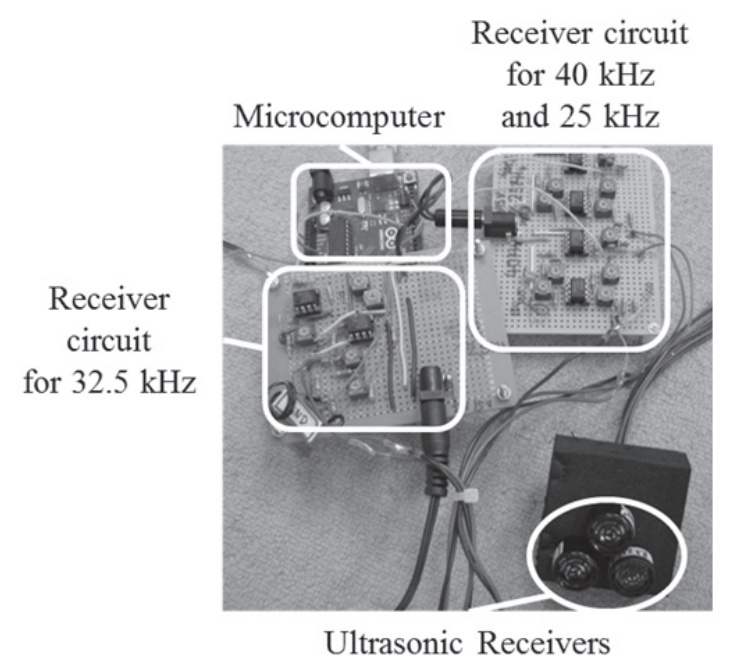

Fig. 4. Photograph of receiver module.

$\mathrm{m} / \mathrm{s}$ とすれば，最大伝搬遅延時間は $26.5 \mathrm{~ms}$ となる. 従って, 測位間隔を $30 \mathrm{~ms}$ にするには, 超音波の検出 と位置計算を $3.5 \mathrm{~ms}$ で行う必要がある.

本手法では，2.2 節，2.3 節で述べたように，超音波 検出に送信機ごとのアナログ回路を用い，位置計算も 高速化している.

\section{3 超音波測位装置の実装と評価}

本節では，提案手法を検証するためのプロトタイプ システムについて述べ, 各構成要素について評価を行 う。受信機側のマイコンには, 広く利用されているロ ーエンドマイコン搭載で, 動作クロック $16 \mathrm{MHz}$ の ArduinoUno を用いた。簡単のため, 送受信機の時刻 


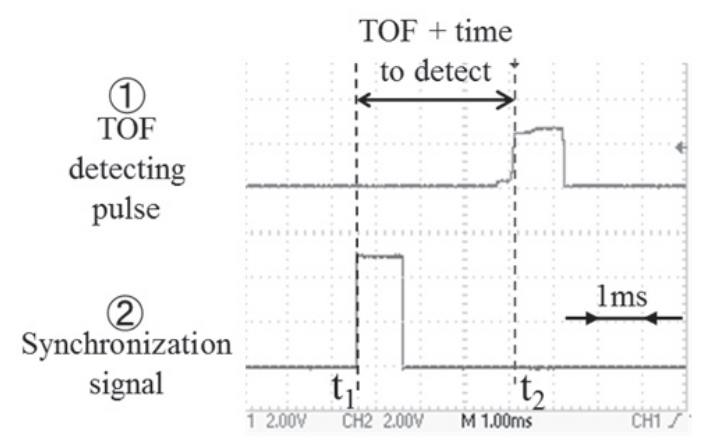

Fig. 5. Waveform of TOF detection in receiver unit.

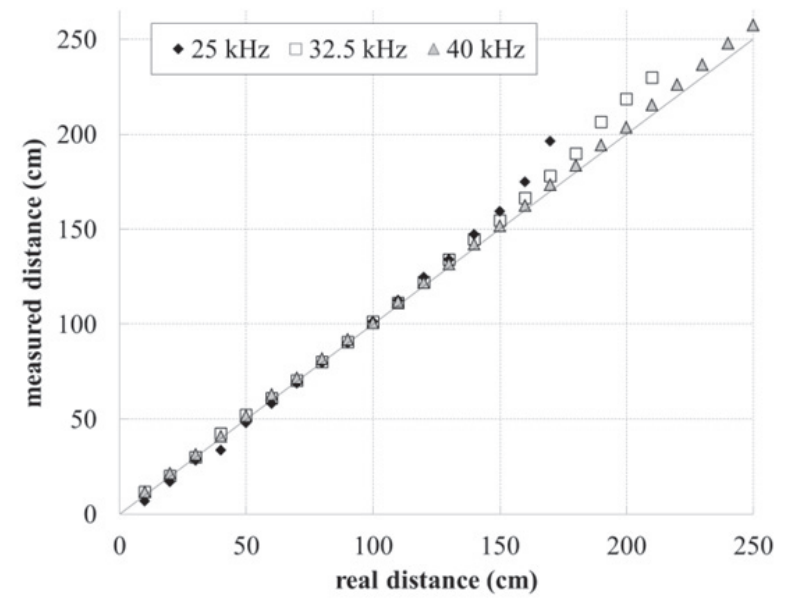

Fig. 6. Real distance vs. measured distance.

同期には有線通信を用いた。

\section{1 超音波送受信機}

開発した送信機を Fig. 3 に, 受信機を Fig. 4 に示す. 超音波の送受信には，日本セラミック（株）の $25 \mathrm{kHz}$ (T2516A1, R2516A1), 32.5 kHz (T3216A1, R3216A1), $40 \mathrm{kHz}$ (T4016A2, R4016A2）超音波トランスデュー サを用いる. これらはスポンジに差し込み, 送受信機 に固定する，送信機では，送信信号を増幅回路により 最大 $15 \mathrm{~V}$ の電圧に増幅して出力する. 受信機では, 微 弱な受信信号をオペアンプ（7032D）による 2 段の反 転増幅回路により最大 625 倍 $(25 \times 25)$ に増幅したあ と，コンデンサにより平滑化する. これをオペアンプ

(7032D) による比較回路で TOF detecting pulse へと変 換する.

\section{2 送受信機間距離の測定実験}

まず開発した送受信機を用いて基礎的な測定実験を
行い，受信機における検出時間，および実距離と測定 距離の誤差を評価する. Fig. 5 に実際の波形を示す. 測定は同一の実距離に対してそれぞれ 100 回行う。超 音波速度の近似值 $v=331.5+0.61 \mathrm{~T}$ よ [12], 室温 $\mathrm{T}=25{ }^{\circ} \mathrm{C}$ して， $v=346 \mathrm{~m} / \mathrm{s}$ を採用する. ただし, 受信機で測定された TOF には検出時間 (検出回路の遅 延時間）が含まれる. そこで事前にゼロ距離の TOF 平 均值を測定しておき，これを検出時間として TOF 測定 值から減じて距離を算出する.

Fig. 6 に測定結果を示す. グラフの横軸に実距離, 縦軸に測定された距離をプロットしている。 また， 25 $\mathrm{kHz}$ では $180 \mathrm{~cm}$ 以上， $32.5 \mathrm{kHz}$ では $230 \mathrm{~cm}$ 以上， 40 $\mathrm{kHz}$ では $260 \mathrm{~cm}$ 以上においては, 超音波の検出に失敗 したためデータなしとした. 各周波数における検出時 間は, $25 \mathrm{kHz}$ では $0.892 \mathrm{~ms}, 32.5 \mathrm{kHz}$ では $0.750 \mathrm{~ms}$, $40 \mathrm{kHz}$ では $0.692 \mathrm{~ms}$ となった.

測定結果より, 実距離が $130 \mathrm{~cm}$ 以下のときはほぼ 全ての周波数・実距離で計測誤差は $5 \mathrm{~cm}$ 以内にとどま つた.このため, この範囲においては最終的な測位に おける誤差 $10 \mathrm{~cm}$ 以内の達成が有望であると考えられ る。しかしながら，実距離が検出に失敗する閾值に近 づくにつれ，実距離よりも長い測定距離が算出される ようになった。特に, $25 \mathrm{kHz}$, 実距離 $170 \mathrm{~cm}$ において は, 測定誤差は平均で $26 \mathrm{~cm}$ にもなった。 これは, 超 音波受信回路で信号を増幅するさいに，ノイズの影響 で, 信号が検出不能になったためと推測される.今後, 最適なトランスデューサの選定, 信号処理回路の最適 化などにより, 測距特性の減衰を 5\%程度以内に改善 し, 到達距離を実用距離の $10 \mathrm{~m}$ まで伸ばしていく予定 である. Fig. 6 等の実測值に基づいて，距離に補正を 加える手法も検討の余地がある.

\section{3 計算時間の測定実験}

次に，位置計算部分のプログラムをマイコンに実装 し，計算時間を評価する。評価対象のプログラムは以 下の 3 つである.

- (1)〜(3) の非線形方程式をニュートン法により計 算するプログラム

- (4), (5) の 2 元 1 次連立方程式をクラメールの公 式により計算するプログラム

- (6) (8) の 3 元 1 次連立方程式をクラメールの公 式により計算するプログラム

各プログラムをマイコンに実装した上で，マイコンに 各送信機の位置と受信機までの距離を与え, それから 


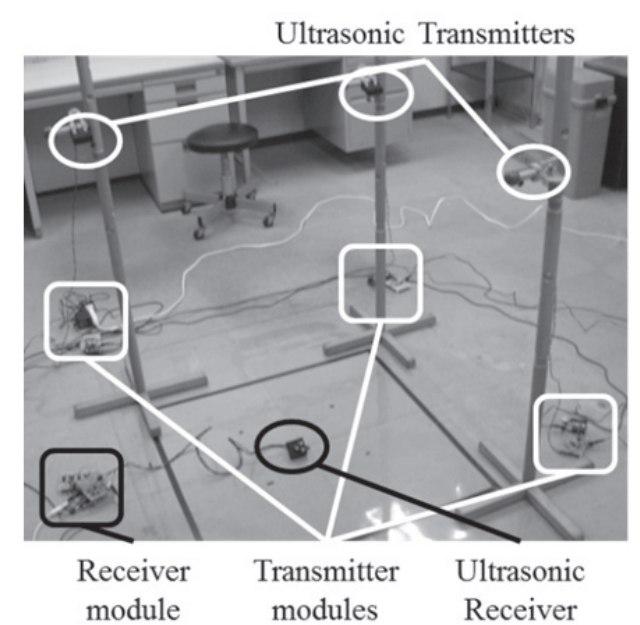

Fig. 7. Photograph of positioning system prototype.

Table 1 calculation time for various equations

\begin{tabular}{|c||c|c|c|}
\hline Target equation & $(1)-(3)$ & $(4),(5)$ & $(6)-(8)$ \\
\hline $\begin{array}{c}\text { Calculation } \\
\text { Time (ms) }\end{array}$ & 135.49 & 0.41 & 0.48 \\
\hline
\end{tabular}

受信機の位置を返すまでの時間を計算時間とする. 測定結果を Table 1 に示す. 非線形方程式をニュート ン法により計算すると, 位置計算には $100 \mathrm{~ms}$ を超える 時間を要し, リアルタイムな測位は困難である.一方, 提案手法（連立 1 次方程式）で計算すると, 2 元・3 元ともに $0.5 \mathrm{~ms}$ 以内で計算が終了し, ニュートン法よ り 280 倍以上高速に計算できた. また, 3.2 節で測定し た検出時間との合計は高々 $1.4 \mathrm{~ms}$ であり, 測位周期の 目標である $30 \mathrm{~ms}$ と比べても十分に短い. ローエンド マイコンでも十分短い時間で位置が計算できるため, 提案方式は低コスト・高速な超音波測位システムとし て十分な有効性を持つと判断できる.

\section{4 超音波測位システムの評価}

3 節で述べた各装置をシステムに統合し，位置測位 の模擬実験を行うことで，システムの評価を行う。構 築した評価システムの写真を Fig. 7 に示す. 3.2 節の評 価結果から, 送受信機間の距離が常に $130 \mathrm{~cm}$ 以下とな るよう，測定範囲を $80 \mathrm{~cm} \times 80 \mathrm{~cm} \times 87 \mathrm{~cm}$ と定めた。 $80 \mathrm{~cm}$ 四方の範囲に 3 つのポールを設置し, 各ポール の高さ $87 \mathrm{~cm}$ の位置に超音波送信機を取り付ける. 測 定範囲内の床面に黒いテープを周回状に貼り付ける. 超音波受信機をテープに沿って移動させながら, 受信 機の位置を $30 \mathrm{~ms}$ ごとに測位し, 2.3 節で述べた式(4), (5)の高速化手法により移動経路を算出した.
測定結果を Fig. 8 に示す。上のグラフは測定された $x, y$ 座標を平面上にプロットしたものである.グレー の線は床面に貼り付けられたテープの軌跡を表し，そ の四隅を $\mathrm{P} 1$ P 4 と表す.また， $25 \mathrm{kHz} ， 32.5 \mathrm{kHz} ， 40$ $\mathrm{kHz}$ の送信機が設置されたポールの座標をそれぞれ T1，T2，T3 と表す. 下のグラフは，矩形 P1-P2-P3-P4 の中心を原点に測定された $x, y$ 座標を極座標変換した ときのP1 方向を始線とした右回りの偏角 $\theta$ をX軸に, 測定された $z$ を $\mathrm{Y}$ 軸にプロットしたものである.

座標 $(x, y)$ につては明らかに系統的な誤差が現れ ている. 特に送信機 2 の近傍では, 絶対誤差が $20 \mathrm{~cm}$, 相対誤差が $28 \%$ あ, その原因は現在調査中である. 測定された $z$ 座標は 0〜 $12.5 \mathrm{~cm}$ の範囲でばらついてい る.

$\mathrm{z}$ 座標の䛊差の要因のひとつとして, (4), (5)式によ り求めた $\mathrm{x}, \mathrm{y}$ 座標を使って $\mathrm{z}$ 座標を求めるさいに発 生する桁落ち誤差が考えられる．桁落ち誤差について は，4つの送信機を高さを変えて設置し，(6) - (8) の導 出式を利用することで削減できると考えられる. $(x, y)$ 座標の系統誤差については，受信機のアナログ回路の 調整不足などが疑われる. 距離測定誤差は部品選択や 回路設計で可能な限り減らすべきであるが，量産時に おいても個体差による測定誤差は不可避である。そこ で本研究では，簡単な較正により測位誤差を抑えるこ とができないか検討を行った。

Fig. 8 における四隅 $(\mathrm{P} 1 \sim \mathrm{P} 4)$ と, その中心点で測位 を行い, 測定結果と真の座標の誤差が最小になるよう, 最小二乗法でアフィン変換の係数を求めた. 得られた アフィン変換は下式の通りである.

$$
\begin{aligned}
& x^{\prime}=0.7813 x+0.0095 y-0.1134 z+5.8306 \\
& y^{\prime}=-0.0605 x+0.6895 y+1.2714 z+7.0920 \\
& \text { このアフィン変換により修正された }(x, y) \text { 座標を, }
\end{aligned}
$$
Fig. 9 に示す. 明らかに誤差は抑制されており, 目標 誤差 $10 \mathrm{~cm}$ から遠くない範囲に収まっている。一方, 本模擬実験では，受信機の $\mathrm{z}$ 座標を一定としたため, アフィン変換により $\mathrm{z}$ 座標を較正することは意味をな さない. しかし, 今後の実験の結果, $\mathrm{z}$ 軸方向にも系 統誤差が見られるのであれば，同様な方法で誤差を抑 制できる. 本研究の目的は, 簡易で安価なシステムを 構築することであるから, 構築要素 (送受信デバイス, アナログ回路，マイコン）にも安価な汎用品を選択し ている. 測定誤差を減らすためにシステムの改良は必 須であるが，高価あるいは入手困難な部品の使用は避 けたい, 一方で, システムの較正, 特にアフィン変換 

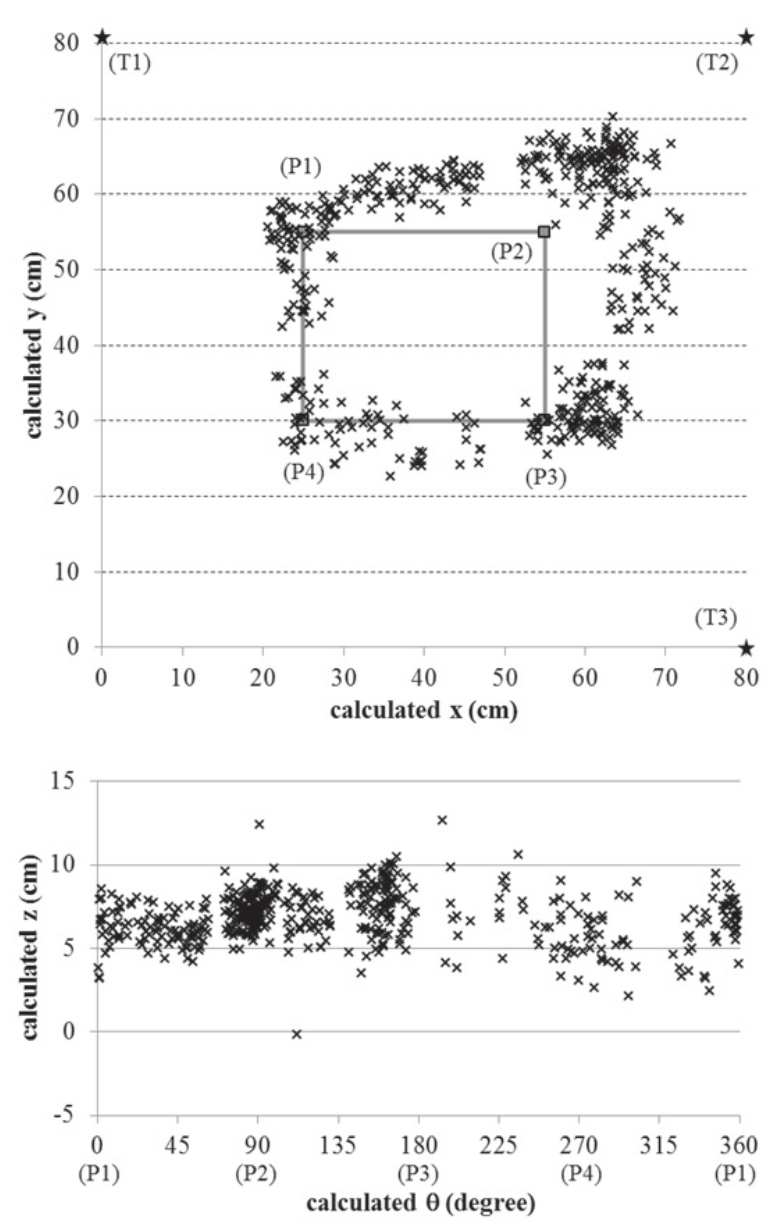

Fig. 8. Result of positioning experiment before calibration.

のような簡易な補正であれば，計算能力の限られたマ イコンでも測位頻度を下げることなく対処できる. 較 正方法については今後詳細な検討が必要であるが，本 研究の目的には有望な選択肢であると考えている.

\section{5 結言}

本研究では, 室内などの限られた範囲での利用を想 定し, 周波数の異なる超音波を用いた位置測位システ 厶を提案した. 測位周期 $30 \mathrm{~ms}$, 測位誤差 $10 \mathrm{~cm}$ 以内 を目標に開発を行い, プロトタイプを構築した結果, 目標值の実現が有望視される評価結果が得られた。

今後は, より広い空間, あるいは障害物が存在する 空間において利用できるシステムを構築・評価して, その実用性と課題を明らかにする必要がある。そのた めには，特に送受信機の改良と測定誤差要因の解明が 急務である。

(2015 年 2 月 23 日受付)

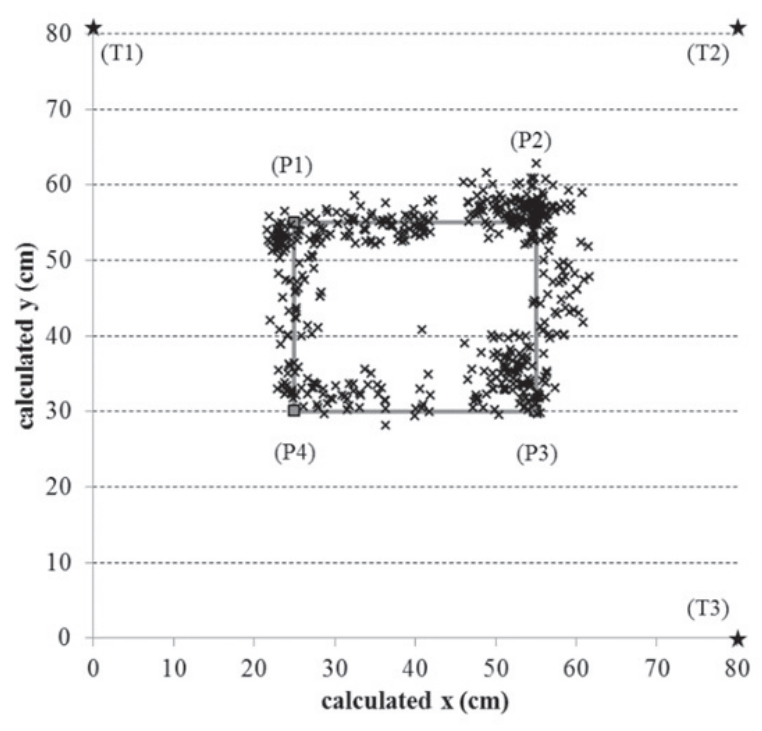

Fig. 9. Result of positioning experiment after calibration.

\section{参考文献}

[1] 坂井丈泰, GPS 技術入門, 東京電機大学出版局, 2003.

[2] 歩夕出す屋内測位，日経エレクトロニクス, 2013 年 5 月 27 日号, no. 1109, pp. 27-41.

[3] J. Hightower, C. Vakili, G. Borriello, and R. Want, Design and calibration of the SpotON ad-hoc location sensing system, unpublished, 2001.

[4] H. Koyuncu, A survey of indoor positioning and object locating systems, Journal of Computer Science and Network, vol. 10, no. 5, pp. 121-128, 2010.

[5] F. Ijaz, C.Lee, Indoor positioning: A review of indoor ultrasonic positioning systems, Proc. 15th Int'l Conf. Advanced Communication Technology (ICACT 2013), pp. 1146-1150, 2013.

[6] N. B. Priyantha, The cricket indoor location system, Ph.D. Thesis, MIT, June 2005.

[7] M. Hazas and A. Ward, A novel broadband ultrasonic location system, Proc. 4th Int'l Conf. Ubiquitous Computing (UbiComp 2002), pp. 264-280, 2002.

[8] Y. Fukuju, M. Minami, H. Morikawa and T. Aoyama, DOLPHIN: an autonomous indoor positioning system in ubiquitous computing environment, Proc. 9th Workshop on Software Technologies for Future Embedded Systems (SEUS 2013), pp. 53-56, 2003.

[9] 鈴木, 宇佐美, 伊与田, 渡辺，スペクトル拡散超音波に よる距離計測のためのリアルタイム相関演算, 計測自 動制御学会論文集, vol. 46, no. 7, pp. 357-364, 2010.

[10］秋山，須永，五百蔵，田中，超音波センサを用いた広域 屋内測位システムの構成と検証実験, 測位航法学会論 文誌, vol. 3, no. 1, pp. 1-8, 2012.

[11] 鈴木, 伊与田, リアルタイム超音波屋内測位システム におけるスペクトル拡散変調による計測性能の向上, 計測自動制御学会論文集, vol. 49, no. 5, pp. 512-520, 2013.

[12] 東京天文台, 理科年表 2014 (机上版), 丸善出版, 2013. 